\section{UDC 338.48:614.46 \\ JEL Classification F 01 \\ MELNYCHENKO Svitlana}

E-mail: melnichenko@knute.edu.ua ORCID: 0000-0002-5162-6324

MYKHAILYCHENKO Hanna

E-mail:h.mykhailichenko@knute.edu.ua ORCID:0000-0001-7066-6527

MEZENTSEVA Hanna

E-mail:fanafura@gmail.com ORCID:0000-0001-7174-1437
DOI: https://doi.org/10.31617/zt.knute.2020(113)02

Doctor of Economics, Professor, Vice-Rector on Scientific Work, Kyiv National University of Trade and Economics 19, Kyoto str., Kyiv, 02156, Ukraine

Doctor of Economics, Professor, Professor at the Department of Tourism and Recreation, Kyiv National University of Trade and Economics 19, Kyoto str., Kyiv, 02156, Ukraine

Director of «MIA» travel agency

\title{
TOURISM SPHERE: WAY OUT FROM QUARANTINE
}

The results of the comparative analysis of tourism development in the conditions of the global pandemic COVID-19 are presented. Government programs for overcoming the crisis are generalized. An effective mechanism for restoring the functioning of domestic tourism entities for the period and after quarantine through the implementation of priority measures has been developed.

Keywords: tourism, tourist arrivals, tourist flow, tourism enterprises, taxation, pandemic COVID-19, post-quarantine period.

Background. The COVID-19 pandemic, which provoked the global economic crisis, had a mixed impact and serious consequences for sustainable development in the tourism sector. According to forecasts, in the world the fall in GDP from April 2020 is $3 \%$, in the European Union $7.1 \%$, in developing European countries (Albania, Belarus, Bosnia and Herzegovina, Bulgaria, Croatia, Hungary, Kosovo, Moldova, Montenegro, Northern Macedonia, Poland, Romania, Russia, Serbia, Turkey, Ukraine) $5.2 \%$, in Ukraine - $7.7 \%$ [1]. Restrictions on movement have led to significant losses in tourism revenues into the economies of countries. The tourism sector has suffered the most from the pandemic, as, according to UN forecasts, in 2020 the annual flow of tourists (1.4 billion people) will decrease by one and a half times [2]. According to the World Tourism Organization (UNWTO), the number of international tourist arrivals could be reduced by $30 \%$, which will reduce revenues from international tourism by almost $\$ 45$ billion USA [3].

The share of tourism in Ukraine's GDP will be about $3-4 \%$, which is much less than the international average (10\%) [1]. This indicates a slight impact of tourism on the country's economy. However, the creation of a tourist product involves various areas of economic activity: hotel and restaurant economy, passenger rail, sea, river, air and other land transport, insurance companies, businesses that organize recreation and entertainment, and

(C) Melnychenko S., Mykhailychenko H., Mezentseva H., 2020 
others who suffer from the continuation of quarantine measures and relevant restrictions on movement and border crossing. According to the UNWTO, the development of tourism is considered one of the ways out of previous crises, which solved not only economic but also social problems, one of which is the reduction of jobs and, consequently, the growth of the unemployed [3]. The unemployment rate in Ukraine increased from $8.5 \%$ in 2019 to $10 \%$ in 2020 [1], and according to the Chamber of Commerce and Industry of Ukraine, the number of unemployed is 2.5 million people (these are officially employed Ukrainians) [4]. The destabilization of the world economy caused by quarantine measures requires the definition of an actions plan for countries in overcoming the crisis, in particular through the development of tourism.

Analysis of recent research and publications. The works of Ukrainian scientists: M. Boiko, M. Bosovska, O. Vysochan, V. Herasymenko, L. Kovalenko, N. Kolotova, A. Mazaraki, M. Malska, H. Mykhailichenko, N. Opanasiuk, A. Okhrymenko, T. Tkachenko [5-15] are dedicated to the research of integration processes, value-oriented management, innovative and strategic development of tourism, the development of national tourist system and the system of legal regulation of tourism. Foreign scientists and practitioners A. Alam, M. Ahmed, R. Brokai, K. Gadar, D. Airy, M. Malik [16-18] and others studied the issues of sustainable tourism development, its role in attracting foreign investment. However, the way out of countries from the economic crisis after the COVID-19 pandemic, including through stabilization measures for tourism development, has not been sufficiently covered.

The aim of this article is to publish the results of a comparative analysis of tourism development in the global pandemic COVID-19, summarize the proposed government programs to overcome the crisis and develop effective mechanisms to restore the functioning of domestic tourism entities in the post-quarantine period.

Materials and methods. The works of domestic scientists and practitioners, periodicals, Internet resources, as well as analytical forecasts of the UNWTO, IMF, UN, HDC (analytical research organization Hotel \& Destination Consulting), the professional community were used in the study. General scientific methods of scientific research are used to study the material: analysis and synthesis, abstraction and concretization, and empirical methods of systematization and generalization.

Research results. Last year, an increase in the number of international arrivals by $3.8 \%$ was observed in the world (figure 1) [19], but the spread of viral infection COVID-19 led to a reduction in tourist flows. Only in 2018, tourists from China spent from 130 to 227 billion US dollars outside their country. Therefore, the losses for countries that received Chinese tourists are significant [20]. According to the UNWTO, the flow of tourists in the world for the six months of 2020 decreased by $65 \%$, and falling demand for international travel during this period led to a loss of 460 billion US dollars, which is 5 times higher than the losses of the tourism business during the global economic crisis of 2009 [20]. The World 
Business Travel Association estimates that the tourism industry will lose up to $\$ 820$ billion USA on business tourism [20].

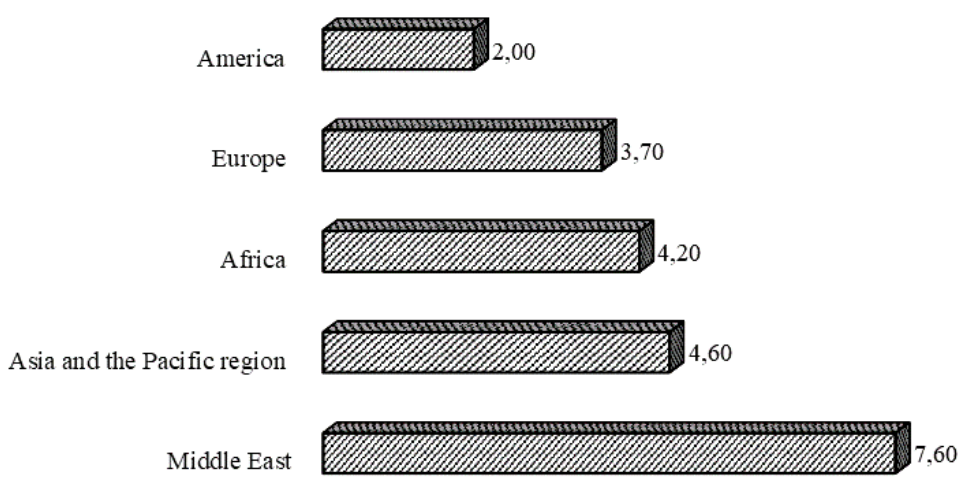

Figure 1. Growth in the number of international arrivals in 2019 by regions of the world, \%

Source: developed by [19].

The most affected by the pandemic are Asian countries, where the flow of tourists has decreased by $72 \%$, Europe - by $66 \%$, Africa and the Middle East $-57 \%$, America - $55 \%$ [21]. The reduction in the flow of tourists during this period in the regions of the world through COVID-19 has led to billions in losses worldwide: The United States has already lost 24 billion dollars USA, EU countries -1 billion euros, Italy -8 billion dollars USA, Thailand - 15 billion dollars USA [21].

In Ukraine, despite the small share of tourism in GDP, the tourism business has also undergone significant changes. Over the last five years, the share of tourists applying for services to travel companies has been gradually increasing. In 2019, the number of tourists served by tour operators and travel agents has tripled compared to 2015, including incoming -5.7 times, outgoing -3.4 times, domestic -1.5 times (figure 2).

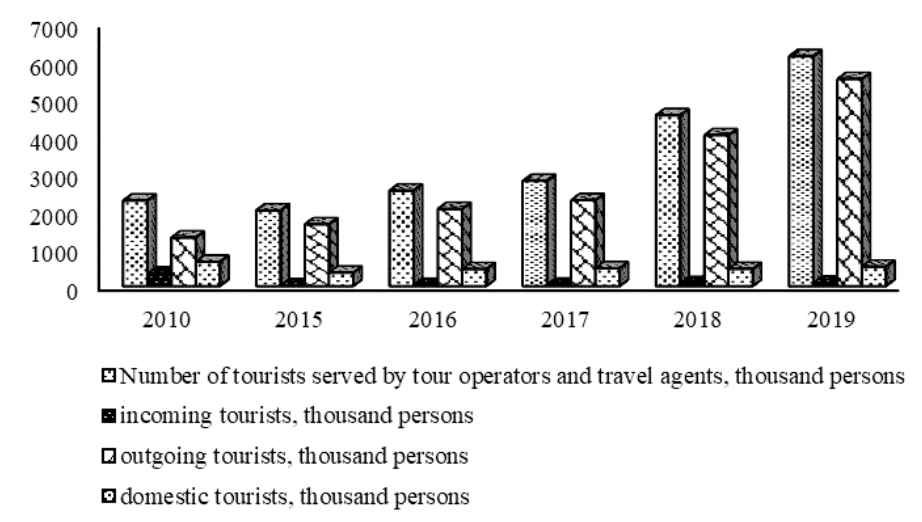

Figure 2. Dynamics of the number of tourists served by tour operators and travel agents, thousand persons

Source: developed by [22]. 
The global quarantine in 2020 had a negative impact on international tourism statistics, however, to some extent contributed to the growth of the share of domestic tourists in Ukraine. At the same time, according to Ukrainian tourism experts, it is currently difficult to obtain reliable data on domestic tourist flows, as a significant part of accommodation facilities operate informally and, as a result, do not pay taxes and tourist tax. According to "Vodafone Ukraine», the number of subscribers in the summer season 2020 in Ukrainian resorts increased compared to the same period last year by 30-170\% (figure 3) [2]. This indicates an increase in the number of tourists who use the services of travel agencies and those who organize their holidays on their own.

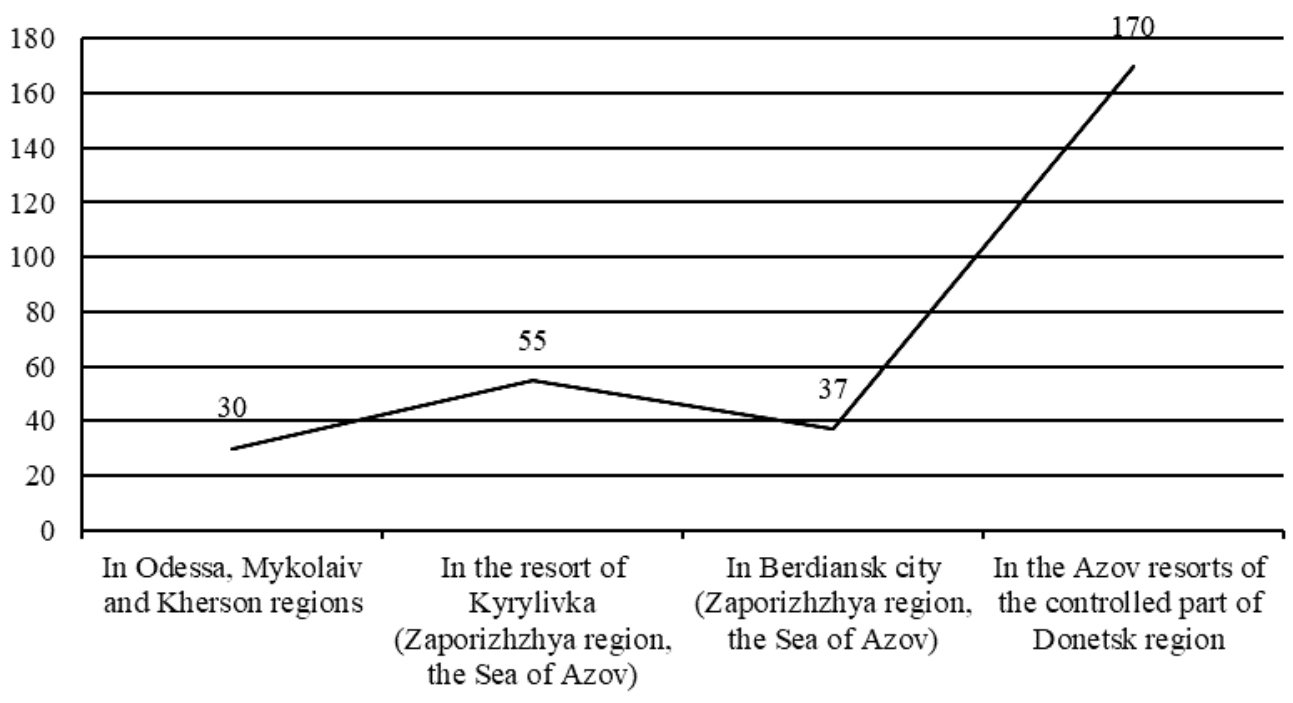

Figure 3. Growth in the number of subscribers in the summer of $2020, \%$

Source: developed by [2].

The opposite results were obtained by the sociological group «Rating» thanks to a survey of Ukrainian citizens in August 2020: 66 \% of Ukrainians were not on vacation at all and did not plan. The reason is not only the closed borders due to the spread of coronavirus infection, but also the termination / closure of enterprises. According to a survey conducted by the Union of Ukrainian Entrepreneurs, only $58 \%$ of enterprises, mostly small and medium-sized businesses, continue to operate, $29 \%$ have completely stopped the activity (microbusiness). At the same time, $42 \%$ of respondents partially or completely reduced their staff, $63 \%$ - plan to reduce by the end of quarantine [23] (figure 4). 


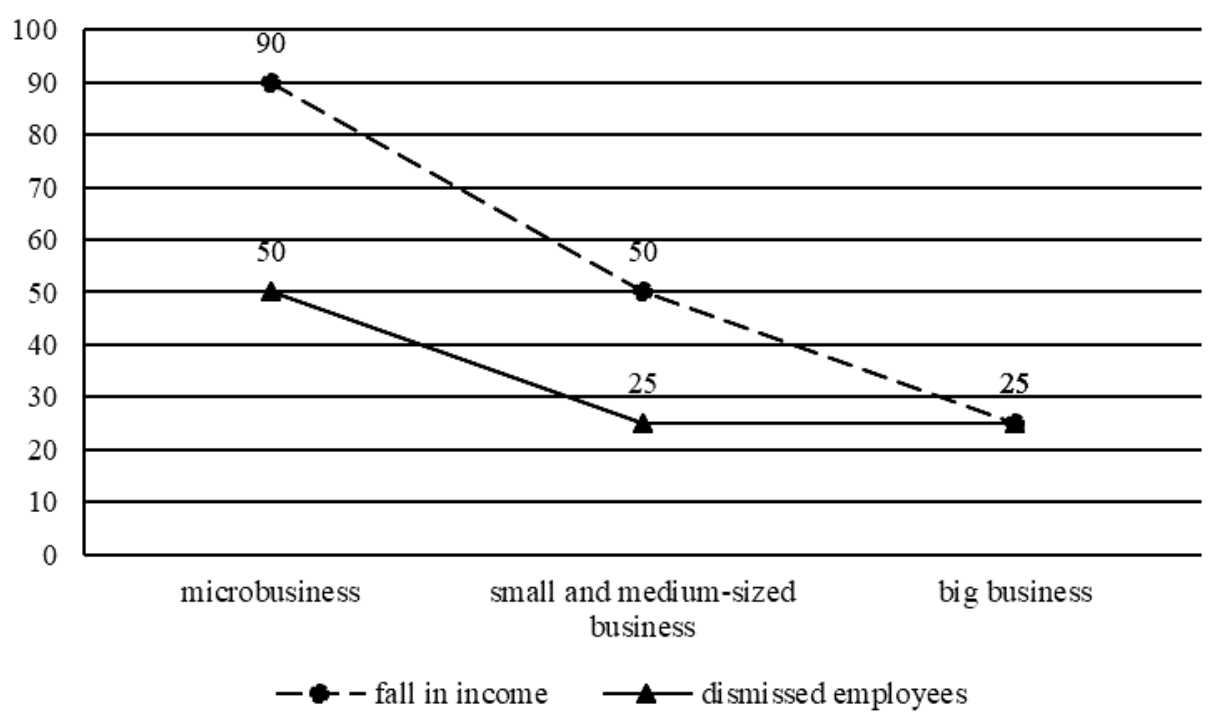

Figure 4. Dynamics of income of Ukrainian enterprises and the number of their employees, $\%$

Source: developed by [2].

The most vulnerable are cultural institutions and tourism businesses. Thus, among the total number of tourist enterprises, $88.5 \%$ account for travel agencies and business entities engaged in excursion activities, which belong to microbusiness. In addition, out of $11.5 \%$ of tour operators, it is mostly microbusiness that is at risk [22].

The UNWTO General Secretary applied to partners in the European Commission, the UN system and institutions of the Bretton Woods Agreement with a call to support tourism in such a complex global situation by concrete actions (according to the IMF, way out from the global crisis will continue at least 5 years) [24].

At the beginning of the quarantine, the Ukrainian government took measures to help support business and partially reduce the negative impact of its consequences: in particular, changes were made to the state budget (providing soft loans to small and medium-sized businesses while maintaining $80 \%$ of jobs and wages to employees); a stabilization fund was created to counteract the coronavirus; provided soft loans to small and medium-sized businesses; allocated funds to compensate for interests on existing loans for micro and small enterprises (UAH 4 billion); available loans programs were expanded (5-7-9\%); secured loans with state investment guarantees (UAH 24 billion); developed a program to support creative industries (UAH 1.6 billion); zero declaration and taxes on withdrawn capital were introduced; the deadline for payment of taxes on land, land rent and real estate tax, which was to be paid in April 2020, has been extended to June 30, 2020, similar taxes for March 2020 have been abolished; provided temporary unemployment benefits for those who lost 
their jobs as a result of the COVID-19 pandemic (2/3 of the amount of wages for each reduced working hour, but not more than the established minimum monthly wage), pensions and unemployment benefits were increased, inspections and penalties for various violations were abolished, and small businesses were released from the single social contribution [25].

At the same time, the Union of Ukrainian Entrepreneurs considers it necessary to temporarily abolish $I T$, exempt the profits of enterprises from taxation in the most vulnerable areas, including cultural institutions and tourism businesses, provide partial assistance to employers for their employees, whose time and volume of work are reduced through quarantine [1;23].

According to forecasts, the recovery of the economic situation in the world will take almost five years, so the efforts of the Ukrainian government and entrepreneurs should be focused primarily on the development of domestic tourism (figure 5).

\begin{tabular}{|c|c|c|}
\hline & & Repair of highways \\
\hline \multirow[t]{3}{*}{ State level } & $\longrightarrow$ & Formation of national information infrastructure \\
\hline & & Deferral of tax and debt obligations \\
\hline & \multirow{4}{*}{$\Longrightarrow$} & $\begin{array}{l}\text { Reproduction of land and water resources, natural } \\
\text { complexes }\end{array}$ \\
\hline \multirow{3}{*}{ Local level } & & Prohibition of coastal zone construction \\
\hline & & $\begin{array}{l}\text { Formation and development of the national ecological } \\
\text { network }\end{array}$ \\
\hline & & Targeted use of funds from the tourist tax \\
\hline \multirow{2}{*}{ Micro level } & \multirow{4}{*}{$\longrightarrow$} & Withdrawal of business from the «shadow» \\
\hline & & $\begin{array}{l}\text { Ensuring compliance between price and quality } \\
\text { of service }\end{array}$ \\
\hline & & Development of various types of domestic tourism \\
\hline & & $\begin{array}{l}\text { Implementation and compliance with anti-epidemic } \\
\text { measures }\end{array}$ \\
\hline
\end{tabular}

Figure 5. Priority measures for the restoration of the tourism sector in Ukraine

Source: developed by the authors.

With regard to government actions, the continuation in 2020 of works to improve the quality of transport infrastructure is one of the most 
important factors in the development of not only the country's economy in general, but also the tourism sector in particular. According to the State Agency of Motor Roads of Ukraine, in $20192407.5 \mathrm{~km}$ of roads were restored, including $930.5 \mathrm{~km}$ of roads of state importance were built and repaired. This year it is planned to repair more than 4 thousand $\mathrm{km}$ of roads of local and state importance [26]. Satisfactory condition of transport connections and access roads to tourist destinations is the key to success.

The formation of a national information infrastructure to support tourism activities with the possibility of further integration into the interstate network, which will eliminate information barriers between the subjects of creating a tourism product, will provide conditions for finding new markets.

To eliminate the consequences of the COVID-19 pandemic in the field of tourism and increase budget revenues from it, regional and local councils need to: ensure the reproduction of land and water resources, natural complexes, forbid the construction of the coastal strip, which is dictated not only by the Land Code of Ukraine [27], but also the need to protect water objects from pollution and choking up. It is important to preserve biological and landscape diversity with the formation and development of the national ecological network in order to increase the natural resource potential of Ukraine.

Another important factor is the targeted use of funds from the local tourist tax. Only in 2019, local budgets received UAH 196.2 million, which is twice higher the indicator of previous period. However, the funds are mostly not used for their intended purpose, at the same time they can be used for the construction of tourist facilities and access roads to them [28].

The main tasks for business entities are: to bring business out of the «shadow», which will help fill local and state budgets and strengthen control over the epidemic situation in the country; bringing quality in line with the price by improving the level of quality of service provision without a significant increase in prices (although this is the most obvious way to compensate for lost profits through quarantine).

The increase in the number of unemployed due to the liquidation of businesses or the reduction of employees, the return of Ukrainian citizens from earnings and, as a result, the deterioration of the financial situation of the population will shift priorities towards inbound and domestic tourism. Therefore, it is worth developing new, little-known types of tourism, including medical and inclusive. Taking into account that in Ukraine the cost of providing medical services is twice lower than in European countries, and the quality is quite high, a significant number of foreign citizens prefer Ukrainian medical tourism. At the same time, the lack of information support for the development of medical tourism, the lack of official statistics on this category of tourists requires increasing the attractiveness through the promotion of medical institutions, medical natural resources of Ukraine, medical staff. 
In order to socially integrate people with disabilities, ensuring equal rights for all categories of the population to rest, one of the priority types of tourism should be inclusive. According to the World Health Organization, almost $15 \%$ of the world's population has some form of disability [29]. One third of the world's population (married couples, children and guardians of people with disabilities) can also become potential consumers of inclusive tourism services [29]. If this type of tourism in Western Europe is developed and profitable, in Ukraine it exists only on paper than in reality. However, it can be a priority that will help restore the tourism sector in the post-quarantine period.

Conclusion. Ukraine's economy, as well as the global one as a whole, suffers from quarantine measures and restrictions, as a result of which there is a budget deficit. The launch of the adaptive quarantine regime has led to the introduction of new social norms of life and the gradual easing of restrictions with constant control of morbidity in the country. The implementation of such a scenario makes it possible to consistently restore all spheres of life. One of the ways to stabilize the economic situation in the world during and after quarantine is the restoration and development of tourism sphere. To do this, it is necessary to implement priority measures at the state, local and micro levels, which will ensure the gradual revival of the tourism sector. Thus, the approved actions plan for the implementation of the Tourism and Resorts Development Strategy for the period up to 2026 [30] requires significant changes caused by the COVID-19 pandemic.

\section{REFERENCES}

1. Pandemija COVID-19 ta i'i' naslidky u sferi turyzmu v Ukrai'ni [The COVID19 pandemic and its consequences in the field of tourism in Ukraine]. Retrieved from http://www.ntoukraine.org/assets/files/EBRD-COVID19Report-UKR.pdf [in Ukrainian].

2. Vnutrishnij turyzm v Ukrai'ni - na pidjomi cherez COVID-19. Chy nadovgo? [Domestic tourism in Ukraine is on the rise through COVID-19. How long?] Retrieved from https://www.radiosvoboda.org/a/vnytrishniy-turyzm-vukraini-covid19/30726545.html [in Ukrainian].

3. Vsemirnaja turisticheskaja organizacija soobshhaet korolju Ispanii o vazhnoj roli turizma v vyhode iz krizisa, vyzvannogo pandemiej COVID-19 [World Tourism Organization informs the King of Spain of the important role of tourism in overcoming the crisis caused by the COVID-19 pandemic]. Retrieved from https://www.unwto.org/ru/news/unwto-underscores-tourismsimportance-for-covid-19-recovery-in-meeting-with-the-king-of-spain [in Russian].

4. Vyhid z karantynu: hto najbil'she postrazhdav cherez prostij i jak ce poznachylosja na biznesi [Way out from quarantine: who suffered the most because of downtime and how it affected the business]. Retrieved from https://dyvys.info/2020/05/26/vyhid-z-karantynu-hto-najbilshe-postrazhdavcherez-prostij-i-yak-tse-poznachylosya-na-biznesi [in Ukrainian]. 
5. Bojko, M. G. (2010). Cinnisno orijentovane upravlinnja v turyzmi [Valueoriented management in tourism]. Kyi'v: Kyi'vs'kyj nacional'nyj torgovel'noekonomichnyj universytet [in Ukrainian].

6. Bosovs'ka, M. V. (2015). Integracijni procesy v turyzmi [Integration processes in tourism]. Kyi'v: Kyi'vs'kyj nacional'nyj torgovel'noekonomichnyj universytet [in Ukrainian].

7. Vysochan, O. S. (2014). Turyzm jak systema [Tourism as a system]. Visnyk nacional'nogo universytetu "L'vivs'ka politehnika» - Bulletin of «Lviv Polytechnic» National University, 79, 25-38 [in Ukrainian].

8. Gerasimenko, V. G. (2013). Razvitie teorii sistemnogo pohoda primenitel'no $\mathrm{k}$ issledovaniju sfery turizma [Development of the theory of a systematic approach in relation to the study of tourism]. Vestnik Nacional'noj akademii turizma - Bulletin of the National Academy of Tourism, 2 (26), 11-15 [in Russian].

9. Kovalenko, L. P., \& Kolotova, N. B. (2016). Kraudfanding - instrument internet-marketyngu innovacijnyh turystychnyh proektiv [Crowdfunding is an internet marketing tool for innovative tourism projects]. Global'ni ta nacional'ni problemy ekonomiky - Global and national economic problems, (Is. 11), (pp. 364-369) [in Ukrainian].

10. Mazaraki, A., Bojko, M., \& Bosovs'ka, M. (2020). Transformacija turyzmu v Suspil'stvi 5.0 [Transformation of tourism in Society 5.0]. Visnyk KNTEU Herald of KNUTE. Kyi'v: KNTEU, 3, 33-54 [in Ukrainian].

11. Mal's'ka, M., Gryshhuk, A., \& Masjuk, Ju. (2015). Vprovadzhennja zarubizhnogo dosvidu strategichnogo upravlinnja rozvytkom turyzmu: mozhlyvosti ta perspektyvy dlja Ukrai'ny [Introduction of foreign experience of strategic management of tourism development: opportunities and prospects for Ukraine] Ekonomichnyj chasopys - Economic magazine, 155, 78-81 [in Ukrainian].

12. Myhajlichenko, G. I. (2012). Innovacijnyj rozvytok turyzmu [Innovative development of tourism]. Kyi'v: Kyi'vs'kyj nacional'nyj torgovel'noekonomichnyj universytet [in Ukrainian].

13. Opanasjuk, N. A. (2017). Systema pravovogo reguljuvannja turyzmu v Ukrai'ni. Innoving u turyzmi; za redakcijeju A. A. Mazaraki [The system of legal regulation of tourism in Ukraine. Innovation in tourism; edited by A. A. Mazaraki]. Kyi'v: Kyi'vs'kyj nacional'nyj torgovel'no-ekonomichnyj universytet, (pp. 279-311) [in Ukrainian].

14. Ohrymenko, A. G. (2019). Nacional'na turystychna systema : monografija / A.G. Ohrymenko - Kyi'v: Kyi'vs'kyj nacional'nyj torgovel'no-ekonomichnyj universytet [in Ukrainian].

15. Tkachenko, T. I. (2015). Ukrai'ns'kyj turyzm $\mathrm{v}$ umovah turbulentnosti [Ukrainian tourism in conditions of turbulence]. Karpats'kyj kraj Carpathian region, 1-2 (6-7), 305 -313 [in Ukrainian].

16. Alam, A., Malik, M., Ahmed, M., \& Gadar, K. (2015). Empirical Analysis of Tourism as a Tool to Increase Foreign Direct Investment in Developing Country: Evidence from Malaysia. Mediterranean Journal Sciences, 6 (4) [in English]. 
17. Brokaj, R. 2014. Local Governments role in the sustainable tourism development of a destination. European Scientific Journal. 10 (31). 56-69 [in English].

18. Airey, D. (2015). 40 years of tourism studies - a remarkable story. Tourism Recreation Research, 40 (1), 6-15 [in English].

19. Torik zafiksovano 1,5 mil'jarda turystychnyh podorozhej - UNWTO [Last year, 1.5 billion tourist trips were recorded - UNWTO]. Retrieved from https://www.ukrinform.ua/rubric-tourism/2859960-torik-zafiksovano-15milarda-turisticnih-podorozej-unwto.html [in Ukrainian].

20. Koronavirus: skil'ky vtrachaje turyzm [Coronavirus: how much tourism is losing]. Retrieved from https://www.bbc.com/ukrainian/features-51870285 [in Ukrainian].

21. V OON ocinyly zbytky $\mathrm{v}$ sferi turyzmu cherez koronavirus [The UN has estimated the losses in the field of tourism due to the coronavirus]. Retrieved from https://lb.ua/world/2020/09/16/466061_oon_otsinili_zbitki_sferi_ turizmu.html [in Ukrainian].

22. Derzhavna sluzhba statystyky Ukrai'ny [State Statistics Service of Ukraine]. Retrieved from http://www.ukrstat.gov.ua [in Ukrainian].

23. Koronavirus VS biznes: polovyna pidpryjemciv protrymajet'sja na karantyni ne bil'she misjacja [Coronavirus VS business: half of entrepreneurs will remain in quarantine for no more than a month]. Retrieved from https://www.epravda.com.ua/publications/2020/04/2/658857/[in Ukrainian].

24. Poslanye yz Madryda: nam nuzhno bustro prosnut'sja [Message from Madrid: We need to wake up quickly]. Retrieved from https://www.unwto.org/ru/news/we-have-to-wake-up-quickly [in Russian].

25. Zhyttja pislja karantynu: jak novyj urjad protystojatyme ekonomichnym vyklykam [Life after quarantine: how the new government will meet the economic challenges]. Retrieved from https:/www.slovoidilo.ua/ 2020/04/20/kolonka/aleksandr-radchuk/ekonomika/zhyttya-pislya-karantynuyak-novyj-uryad-protystoyatyme-ekonomichnym-vyklykam [in Ukrainian].

26. Stalo vidomo, skil'ky kilometriv ukrai'ns'kyh dorig vdalosja vidnovyty v 2019 roci [It became known how many kilometers of Ukrainian roads were restored in 2019]. Retrieved from https://www.unian.ua/economics/transport/ 10822280-stalo-vidomo-skilki-kilometriv-ukrajinskih-dorig-vdalosya-vidnovitiv-2019-roci.html\#: :text=\%C2\%AB\%D0\%A3\%202019\%20\%C2\%AB\%D0\% A3\%D0\%BA\%D1\%80\%D0\%B0\%D0\%B2\%D1\%82\%D0\%BE\%D0\%B4\%D 0\%BE\%D1\%80\%C2\%BB\%20\%D0\%B2\%D0\%B2\%D1\%96\%D0\%B2,\%D1 $\% 81 \% \mathrm{D} 0 \% \mathrm{~B} 5 \% \mathrm{D} 1 \% 80 \% \mathrm{D} 0 \% \mathrm{~B} 5 \% \mathrm{D} 0 \% \mathrm{~B} 4 \% \mathrm{D} 0 \% \mathrm{BD} \% \mathrm{D} 1 \% 96 \% \mathrm{D} 0 \% \mathrm{~B} 9 \%$ $20 \% 2 \mathrm{D} \% 20813 \% 2 \mathrm{C} 6 \% 20 \% \mathrm{D} 0 \% \mathrm{BA} \% \mathrm{D} 0 \% \mathrm{BC}$ [in Ukrainian].

27. Zemel'nyj kodeks Ukrai'ny iz zminamy i dopovnennjamy, vnesenymy Zakonamy Ukrai'ny [Land Code of Ukraine with changes and additions made by the Laws of Ukraine]. Retrieved from https://ips.ligazakon.net/ document/view/T012768?an=1331\&ed=2019_02 07 [in Ukrainian].

28. Nacional'nyj instytut strategichnyh doslidzhen'. Shhodo rozvytku turyzmu v Ukrai'ni v umovah pidvyshhenyh epidemichnyh ryzykiv [National Institute for Strategic Studies. Regarding the development of tourism in Ukraine in conditions of increased epidemic risks]. Retrieved from https://niss.gov.ua/ sites/default/files/2020-06/turyzm-v-ukraini.pdf [in Ukrainian]. 
29. Invalidnist' [Disability]. Retrieved from https://uk.wikipedia.org/ wiki/\%D0\%86\%D0\%BD\%D0\%B2\%D0\%B0\%D0\%BB\%D1\%96\%D0\%B4 $\% \mathrm{D} 0 \% \mathrm{BD} \% \mathrm{D} 1 \% 96 \% \mathrm{D} 1 \% 81 \% \mathrm{D} 1 \% 82 \% \mathrm{D} 1 \% 8 \mathrm{C}$ [in Ukrainian].

30. Pro zatverdzhennja planu zahodiv z realizacii' Strategii' rozvytku turyzmu ta kurortiv na period do 2026 roku u 2019 roci: Nakaz Ministerstva ekonomichnogo rozvytku i torgivli Ukrai'ny vid 5 bereznja 2019 roku № 346 [On approval of the actions plan for the implementation of the Strategy for the development of tourism and resorts for the period up to 2026 in 2019: Order of the Ministry of Economic Development and Trade of Ukraine dated March 5, 2019 № 346]. Retrieved from https://ips.ligazakon.net/document/ view/ME190300 [in Ukrainian].

The article submitted to editor's office on 23.10.2020.

\section{Мельниченко С., Михайліченко Г., Мезенцева Г. Туристична сфера: вихід з карантину.}

Постановка проблеми. Пандемія COVID-19, яка привела до втрати людських життів, спровокувала світову економічну кризу та має серйозні наслідки для стійкого розвитку, неоднозначно вплинула на туристичну сферу. Обмеження можливості пересування призвели до значних втрат туристичних надходжень в економіку краӥн. У світі вважають, щяо туристична сфера постраждала від пандемії найбільше. Частка туризму у ВВП України значно менша порівняно з міжнародним середнім показником. Це може свідчити про незначний вплив туризму на економіку країни. Однак у створенні туристичного продукту задіяні різні сфери економічної діяльності, щуо потерпають через продовження карантинних заходів $i$ діючих обмежень щзодо пересування та перетину кордону. За інформацією UNWTO саме розвиток туризму був одним із напрямів виходу з криз, який вирішив не тільки економічні, а й сочіальні проблеми, однією зяких є скорочення робочих місиь $i$ як результат зростання безробітних. Дестабілізація світової економіки, викликана карантинними заходами, вимагає визначення дій виходу країн з кризи, зокрема через розвиток туристичної сфери.

Аналіз останніх досліджень і публікацій показав, щь, попри окремі дослідження щзоо інтеграчійних прочесів, иіннісно орієнтованого управління, інновачійного та стратегічного розвитку туризму, національної туристичної системи та системи правового регулювання туризму, вихід країн з економічної кризи після пандемії COVID-19, зокрема стабілізаційні заходи розвитку туризму, висвітлено недостатньо.

Метою статmі є оприлюднення результатів порівняльного аналізу розвитку туризму в умовах світової пандемії COVID-19, узагальнення запропонованих урядових програм виходу з кризової ситуаџї̈ та розроблення дієвих механізмів відновлення функціонування вітчизняних суб'єктів туристичної діяльності після карантину.

Матеріали та методи. У прочесі дослідження використовувались праці вітчизняних науковиів $і$ практиків, матеріали періодичного друку, інтернет-ресурси, а також аналітичні прогнози UNWTO, МВФ, ООН, HDC (аналітично-дослідницька організачія Hotel \& Destination Consulting), професійної спільноти. Для опрацювання зазначеного матеріалу застосо- 
вано загальнонаукові методи наукового дослідження, зокрема аналізу та синтезу, абстрагування й конкретизації, а також емпіричні - систематизації та узагальнення.

Результати дослідження. Радикальна зміна світової туристичної галузі, щзо зумовлена глобальною кризою через поширення пандемії COVID19, вносить корективи ци у розвиток вітчизняного туризму. Скорочення потоку туристів по регіонах світу через коронавірусну інфекиію призвели до мільярдних збитків у світовому масштабі. Глобальний карантин 2020 року став одним з негативних чинників впливу на значне зменшення в'їзих і виїзних туристів, проте деякою мірою для України є позитивним, оскільки сприяє зростанню кількості внутрішніх туристів. Украӥнський уряд на початку карантину здійснив заходи, які дали можливість підтримати бізнес $і$ частково подолати його наслідки. Враховуючи, що відновлення економічної ситуачї у світі займе приблизно п'ять років, зусилля уряду та підприємців повинні бути спрямовані насамперед на розвиток внутрішнього туризму.

Висновки. Економіка України, як і глобальна в иілому, потерпає від карантинних заходів, щзо призведе до дефіц̧иту бюджету. Запуск адаптивного карантину сприяв переходу на нові соціальні норми життя, зокрема поступове зняття обмежень з постійним контролем захворюваності у країні. Реалізація такого сценарію дає можливість поступово відновлювати усі сфери життя. Одним з напрямів стабілізації економічної ситуації у світі на період та після карантину є відновлення та розвиток туристичної сфрери. Для иього необхідно реалізувати першочергові заходи на державному, місиевому та мікрорівнях, щзо забезпечить поступове відродження туризму.

Ключові слова: туризм, туристичні прибуття, туристичний потік, туристичні підприємства, оподаткування, пандемія COVID-19, посткарантинний період. 